\title{
Evaluation of the quality of cadastral data
}

\author{
Jarosław Taszakowski ${ }^{1 *}$, Urszula Litwin ${ }^{1}$, Arkadiusz Doroż ${ }^{1}$ and Karolina Misiak ${ }^{1}$ \\ ${ }^{1}$ Department of Agricultural Land Surveying, Cadastre and Photogrammetry, University of Agriculture in Krakow, Balicka 253a, \\ 30-198 Krakow, Poland
}

\begin{abstract}
The purpose of the work is to determine the possibility of assessing the quality of cadastral data basing on the system of land and building registry. The study of discrepancies between the descriptive and graphical parts of the of the land and buildings registry was accepted as the scope of research in the field of marking plots and their areas, checking the level of: supplementing registry data with PESEL numbers for private entities and REGON numbers for public entities, completeness of addresses data, verification of documents defining the legal status of real estates and data on border points. The research objects were 14 precincts, including 11 rural ones in the commune of Dąbrowa Tarnowska and 3 in the urban commune of Dąbrowa Tarnowska, located in the Dąbrowski district in the Małopolskie voivodship.
\end{abstract}

\section{Introduction}

Cadastre is an information system that provides collection, updating and sharing information on land, buildings and premises, their owners and any other entities owning or managing the land, buildings or premises [1,2].

The Polish cadastre developed in stages similarly to other cadastral systems in the world $[3,4]$. As a first stage, the inventory of documentation related to the Austrian and Prussian cadastre can be considered, as well as the geodetic and cartographic documentation, which was created in connection with consolidation works in the interwar period as well as documentation produced during the socio-political changes in the postwar years. The next stage was the establishing of a uniform land registry in the whole country. The third stage was and is the computerization of the land and building registry system [5].

The basic task assigned to the real estate cadastre is to collect numerical and descriptive data about land, buildings and premises. It is run by bodies that have a public character. It has rules for its creation, updating and sharing created in accordance with applicable regulations [6].

The most important development trend of the real estate cadastre in Poland is creation of the Integrated Property Information System (IPIS). The legal basis for the functioning of this system is determined by the provisions of the Geodetic and Cartographic Law Act and the provisions of the Regulation of the Council of Ministers of January 17, 2013 regarding the Integrated Cadastral System. [7]. However, among the global development trends of the cadastre, the creation and implementation of a multi-dimensional cadastre should be taken into account [8-11]

The concept of creation of the Integrated Property Information System, was developed in 1999. As a result of the arrangements between the Polish government and the European Commission, the PHARE 2000 program was created - "Creation of the Integrated Cadastral System". It was a joint project of the Main Office of Geodesy and Cartography, the Ministry of Finance and the Ministry of Justice. The idea of the program was to provide access to up-to-date and reliable information about real estates for public administration bodies, entrepreneurs and citizens using electronic technology. [12].

The aim of running the IPIS is to improve the functioning of the state's information system regarding real estates, by creating solutions to ensure data integrity and timeliness (in accordance with the data quality model presented in Figure 1), regarding real estates included in public registers, automation of their update processes, as well as the widest possible use of information collected in these registers for public purposes, taking into account the state of computerization of these registers [13].

The basis of IPIS is the land and buildings registry, which proper functioning is conditioned by the fulfilment of the requirements specified in art. 21 of the Geodetic and Cartographic Law of Purposes and provision of reference data to other systems.

The Integrated Property Information System as a teleinformation system should enable keeping the central repository of copies. It is connected with the update and secure storage of information forming one consistent database. [14]

\footnotetext{
${ }^{*}$ Corresponding author: jaroslaw.taszakowski@urk.edu.pl
} 
The lack of consistency and coherence of data between the land and building registry, land and mortgage registers as well as the abovementioned public registers is still a current and a big problem.. That is why the problem of assessing the functioning of land and building registry as the most important element of IPIS becomes current.

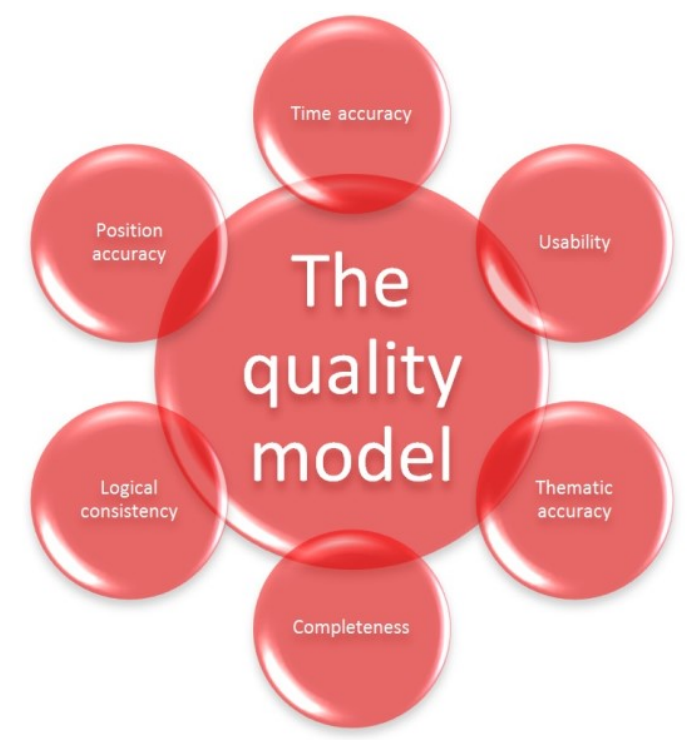

Fig. 1. Data quality model, source: own study.

\section{Description of the research methodology}

The research is aimed at assessing the quality of cadastral data in the context of the implementation of the Integrated Property Information System. The analyses which were carried out refer to the data quality model which was made available by the Head Office of Geodesy and Cartography, namely: logical consistency, accuracy (temporal, thematic and position), usability and completeness. The quality assessment was based on 4 analyses:

- the analysis of discrepancies in registry data between the descriptive and graphical parts,

- the analysis of legal conditions shown in the land and building registry,

- the analysis of completeness of the registry database in the field of:

- PESEL and REGON attributes,

- residential and institutional addresses.

- the analysis of the accuracy of cadastral databases in the field:

- sources of data on the location of border points,

- stabilization code,

- border order code,

0 the mean error of the position of the border point with respect to the first class network.

Basing on the analysis of the source of data on the location of border points and the mean error of the position of the border point in relation to the I-class network, it was checked how many parcels have a legal border and how many parcels have border points with the determination error $0.00-0.30 \mathrm{~m}$.

*Corresponding author: jaroslaw.taszakowski@urk.edu.pl
In order to illustrate the quality of cadastral data in the examined facilities, a ranking of blocks has been prepared, taking into account the quality of the possessed data. For this purpose, the following evaluation criteria and established weights were selected:

- no discrepancies between the graphic part and the descriptive part regarding the number of registered plots (weight 1 ),

- no differences in the area between the graphic and descriptive part (weight 2),

- parcel area determined with the accuracy of 0.0001 ha (weight 1 ),

- land and mortgage register disclosed in the database (in the current and electronic form) (weight 2),

- the PESEL or REGON attribute shown in the database (weight 1),

- address of the owner in the case of natural persons or company headquarters with reference to the institutions shown in the database (weight $1)$,

- $\quad$ each border point is legally approved (weight 2),

- the position error of each border point is in the range $0.00-0.30 \mathrm{~m}$ (weight 3 ).

Next, the coefficient was calculated, which In a very approximate but easy to interpret way determines the completeness, coherence and accuracy of cadastral data in the precincts with reference to both registry units (formula 1).

$$
W_{k}=\frac{x_{i}-x_{\min }}{x_{\max }-x_{\min }}
$$

where:

$\mathrm{W}_{\mathrm{k}}$ - the quality factor of cadastral data in the registry unit

$\mathrm{x}_{\mathrm{i}}$ - the analysed value

$\mathrm{x}_{\max }-$ maximum value

$\mathrm{x}_{\min }-$ minimum value.

\section{The research results}

Below some graphic elaborations will be presented as the research results. They are included in the figures no. 2-12.

In the first analysis, shown in figure 2 , the audit was carried out in the SCAL-SWDE program, it consisted in determining the differences in the identification of the parcels on the map and in the descriptive part of the survey. Then, the areas of registration plots from the evidential database and counted areas based on the vector map were compared. The settlement of parcel areas on the cadastral map was made in the Bentley Microstation V8i program using the MK Power 2015 overlay. 


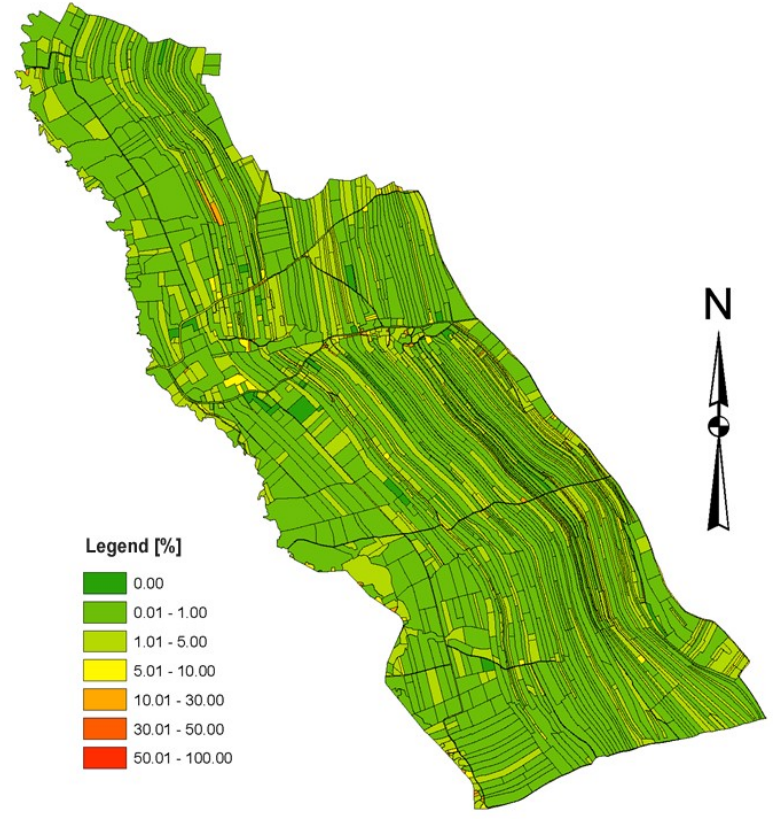

Fig. 2. Discrepancies in the registry data between the descriptive part and the graphical part regarding the compliance of the area of parcels on the example of the Brnik precinct, source: own study.

The analysis of the accuracy of the determination of the surface is aimed at finding plots of land whose surface is not specified in accordance with the guidelines provided for in Polish legal norms, i.e. up to 0.0001 ha. The urban area has $100 \%$ plots of land whose area is specified up to $0.0001 \mathrm{ha}$. The situation in the rural area deviates from legal norms, since most properties have a field of only $0.01 \mathrm{ha}$, which is a consequence of the old legal requirements, allowing the accuracy of determining the area to 0.01 ha. The attached figure shows that the accuracy norms are met only for plots that were subject to geodetic and legal activities and had newly calculated areas.

In the next part of the research, the cadastral databases were analysed in terms of their completeness, accuracy and usability. In the case of legal status of real estate visible in the database of registers, the land and mortgage register is a basic document confirming the right to real estate (over $75 \%$ of all documents). There is a large number of plots where there is no document stating the legal status (about $15 \%$ of the total). The study was carried out in the ESRI ArcGIS program.

\footnotetext{
*Corresponding author: jaroslaw.taszakowski@urk.edu.pl
}

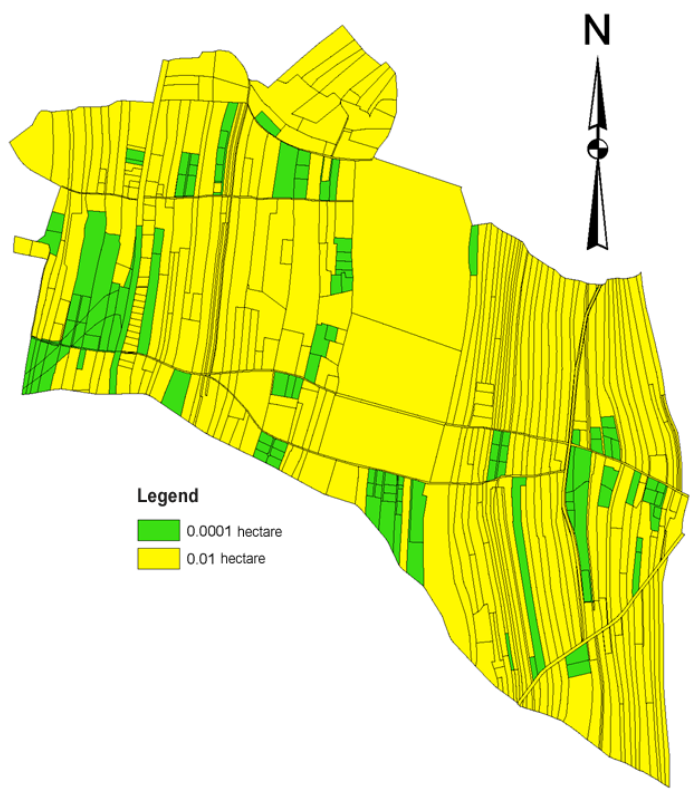

Fig. 3. Analysis of the accuracy of cadastral databases in terms of the accuracy of area determination on the example of the evidence precinct Gruszów Mały, source: own study.

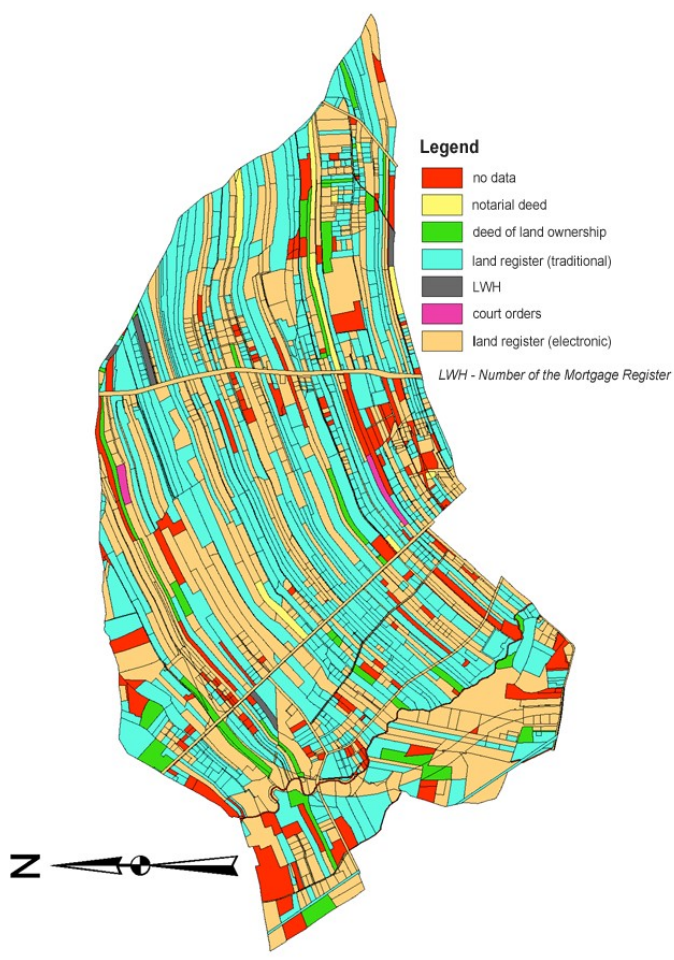

Fig. 4. Analysis of legal conditions within Ruda precinct, source: own study.

The property cadastre shows a lot of data regarding land, buildings, premises and their owners. One of such information is the place of permanent residence or the address of the registered office of the entities. The disclosure of the address in the property cadastre is very important, it allows for correct notification of the site during legal and geodetic works. In the studied area, permanent residence addresses are given to natural persons in more than $98 \%$, and the headquarters of the institutions only in $76.6 \%$. 


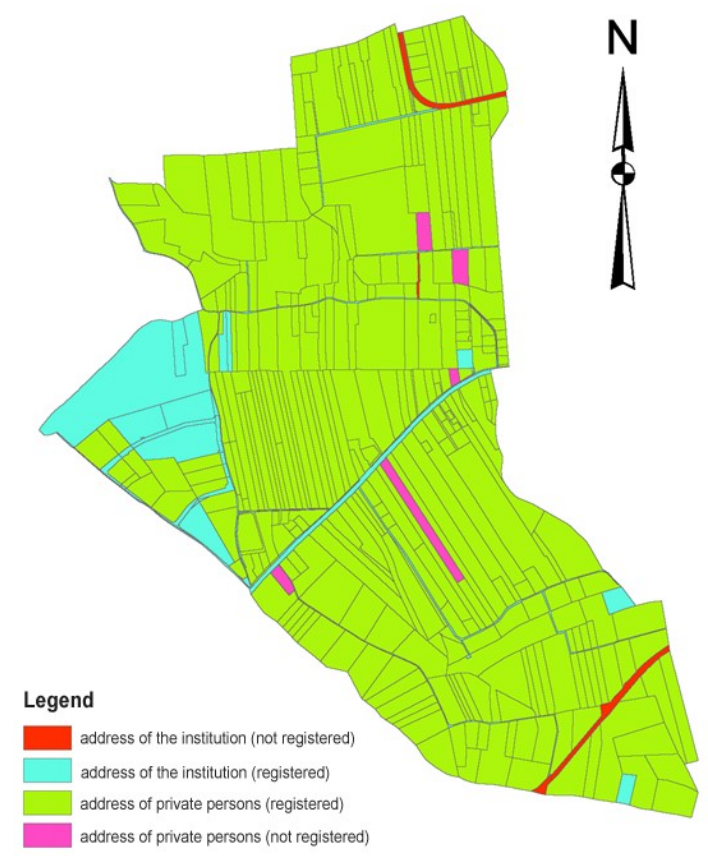

Fig. 5. Analysis of the completeness of the cadastral database in the scope of supplementing the addresses of residences and headquarters of institutions - Morzychna, source: own study.

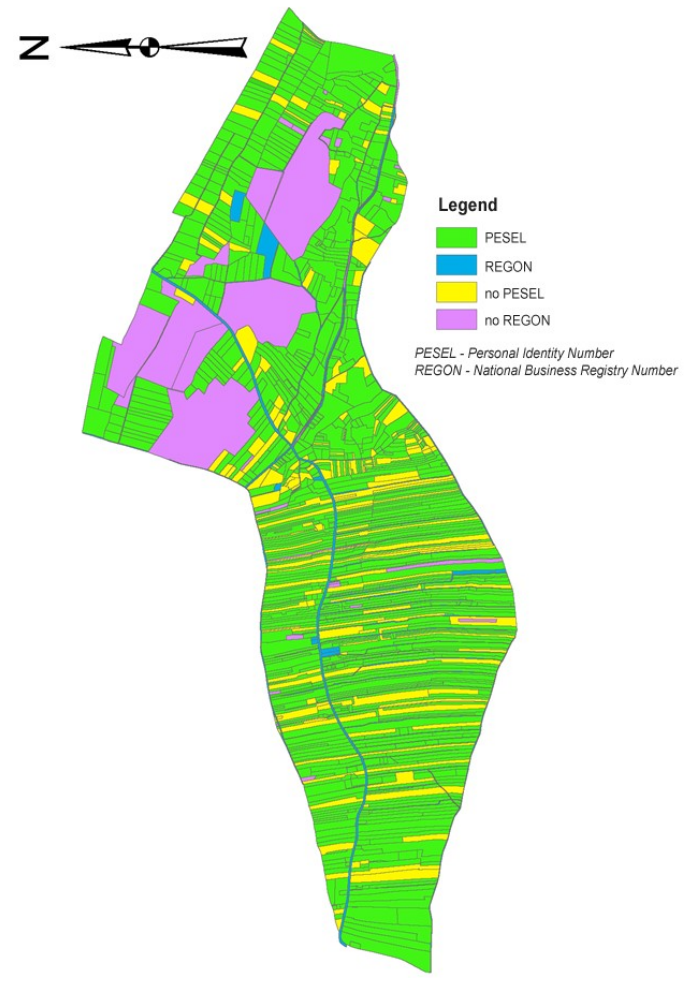

Fig. 6. Analysis of the completeness of the registry database with regard to supplementing the PESEL and REGON attributes on the example of Lipiny, source: own study.

The database was analysed in terms of disclosing the PESEL and REGON attributes. There is no registration area that has a complete set of data about these registers. In both cases, a larger number of plots has a PESEL or REGON disclosed.

The first analysis concerning attributes of border points concerned the source of data on the location of the

\footnotetext{
${ }^{*}$ Corresponding author: jaroslaw.taszakowski@urk.edu.pl
}

border point. The following values of the ZRD attribute are in Polish standards: Attribute 1- geodetic field measurements preceded by delimitation of real estate, resumption of border marks, determination of border points or determination of their location in a different mode:

- Attribute 2 - geodetic field measurements not preceded by delimitation of real estate, resumption of border marks, determination of border points or determination of their location in a different mode.

- Attribute 3 - geodetic photogrammetric measurements of border points whose location has been predetermined in a specified manner, as well as photogrammetric measurements of boundary marks displayed on aerial photographs or orthophoto maps. as a result of their signalling before taking pictures.

- Attribute 4 - geodetic photogrammetric measurements not preceded by determining the boundaries of registration parcels or signalling border signs before taking aerial photographs.

- Attribute 5 - approved projects for the division of real estate or the consolidation and division of real estate.

- Attribute 6 - approved projects for the consolidation or exchange of land.

- Attribute 7 - screen vectorization of the raster map using unified use of geodetic measurements of terrain measurements (linear measures).

- Attribute 8 -screen vectorization of the record raster map without using geodetic measurements of field measurements.

- Attribute 9 - other data sources.

It shows that over $80 \%$ of border points are established on the basis of photogrammetric measurements not predicted by the record boundaries or on-screen vectorization of the raster map using the results of geodetic field measurements.

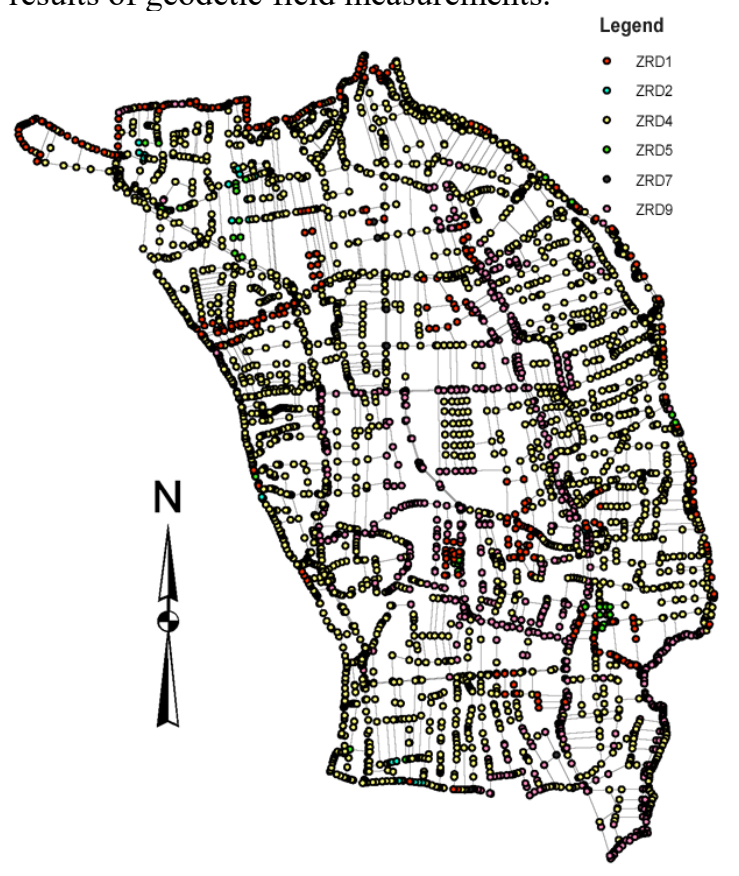

Fig. 7. Values of the data source for the location of the border point within the evidence precinct Sutków, source: own study. 
The data on border points was also analysed in terms of border code and it was established that the area under research "has points on the government: register plot $(93.0 \%)$, registration area $(3.8 \%)$, register unit $(1.2 \%)$, municipality $(1.4 \%))$ and poviat $(0.6 \%)$.

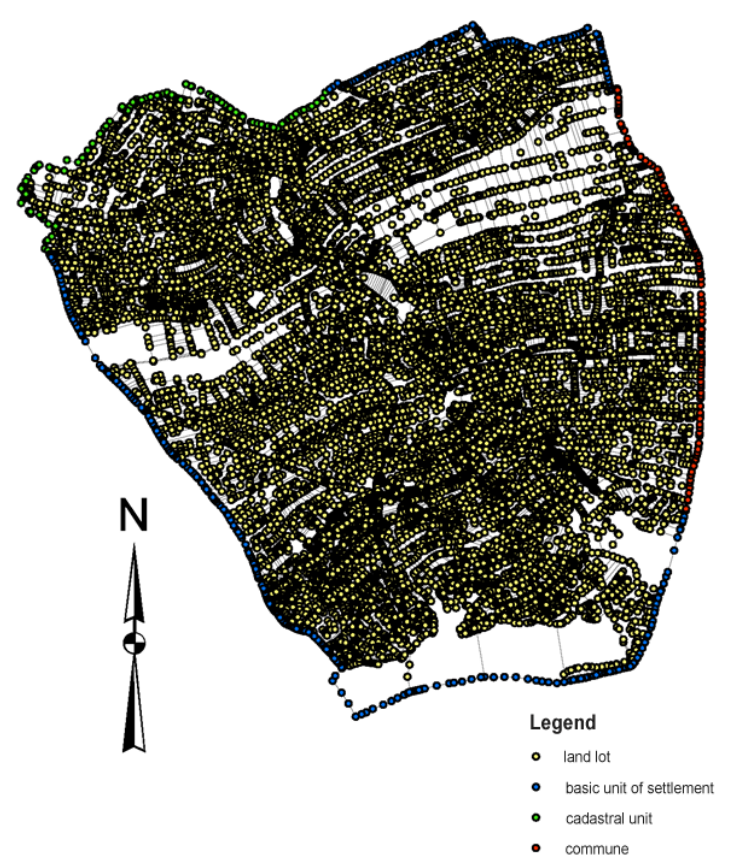

Fig. 8. The values of the code on the border order in Szarwark, source: own study.

The third analysis checked the method of stabilizing border points. It shows that only $3.4 \%$ of border points have stabilization. The rest of the points are either not stabilized $(52.8 \%)$ or there is no information on this subject (43.8\%).

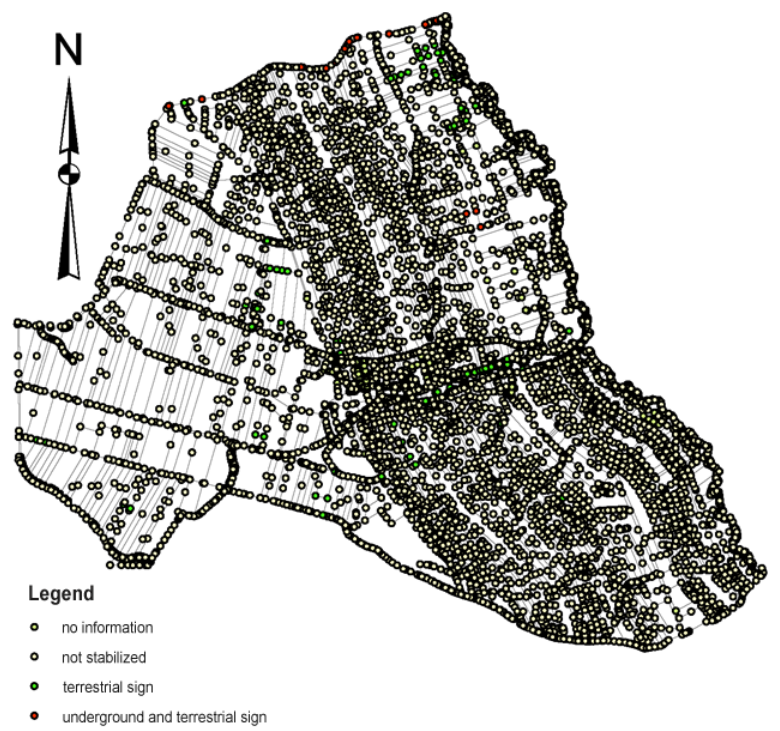

Fig. 9. The values of the border point stabilization code in Żelazówka, source: own study.
Another analysis was the analysis of the accuracy of cadastral databases in terms of the average position error of the boundary point in relation to the first-class geodetic control network. The most points are with the accuracy of $1.51 \mathrm{~m}$ to $3.00 \mathrm{~m}(32.3 \%)$ and $0.00 \mathrm{~m}$ to $0.10 \mathrm{~m}(14.0 \%)$. Once again, the largest problem of the analysed database was revealed, i.e. large gaps, as many as $50.5 \%$ of border points have no specific location error.

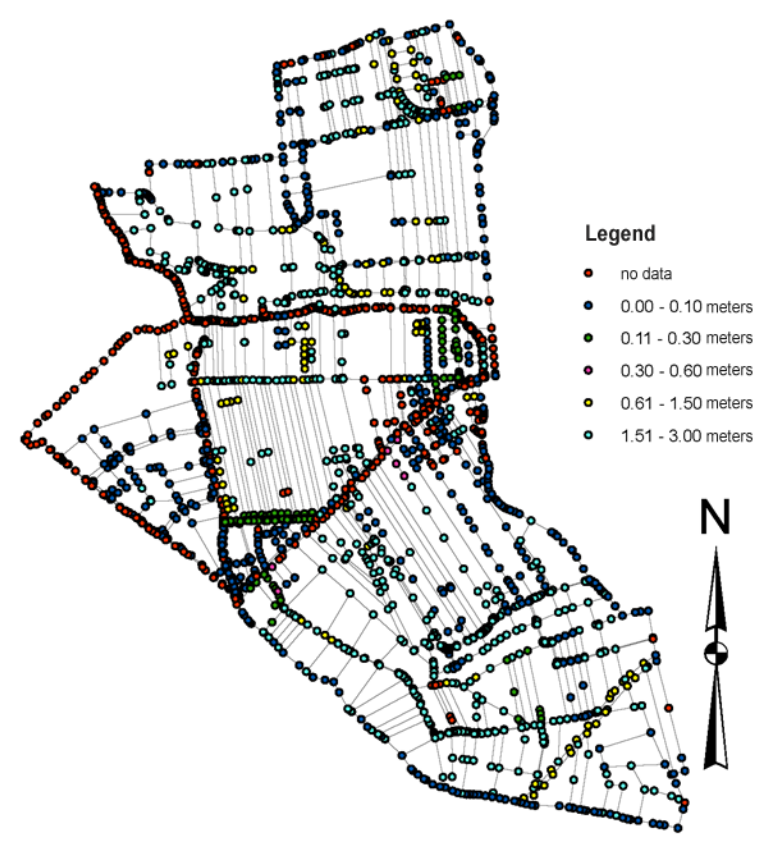

Fig. 10. Average error of the border point relative to the geodetic control network of the 1st class within Morzychna precinct, source: own study.

One of the most interesting analyses in terms of surveying was to check how many plots have all legal boundaries. For this purpose, GIS tools were used, specifically the QGIS program, whose tools allowed to determine the percentage share of points defined legally in relation to all. As a result of the work, it turned out that $10.8 \%$ of registered plots in the area of the city and the commune of Dąbrowa Tarnowska have the entire legal boundary.

Another analysis, also made with the use of GIS tools, concerned the representation of the percentage share of border points determined with an accuracy of $0 \backslash$ 0 to $0.30 \mathrm{~m}$ in relation to all. As for the accuracy of determining the border points, $11.2 \%$ of plots have a set of such border points, where the position error in terms of the geodetic control network of the 1st class is up to $0.30 \mathrm{~m}$.

\footnotetext{
${ }^{*}$ Corresponding author: jaroslaw.taszakowski@urk.edu.pl
} 


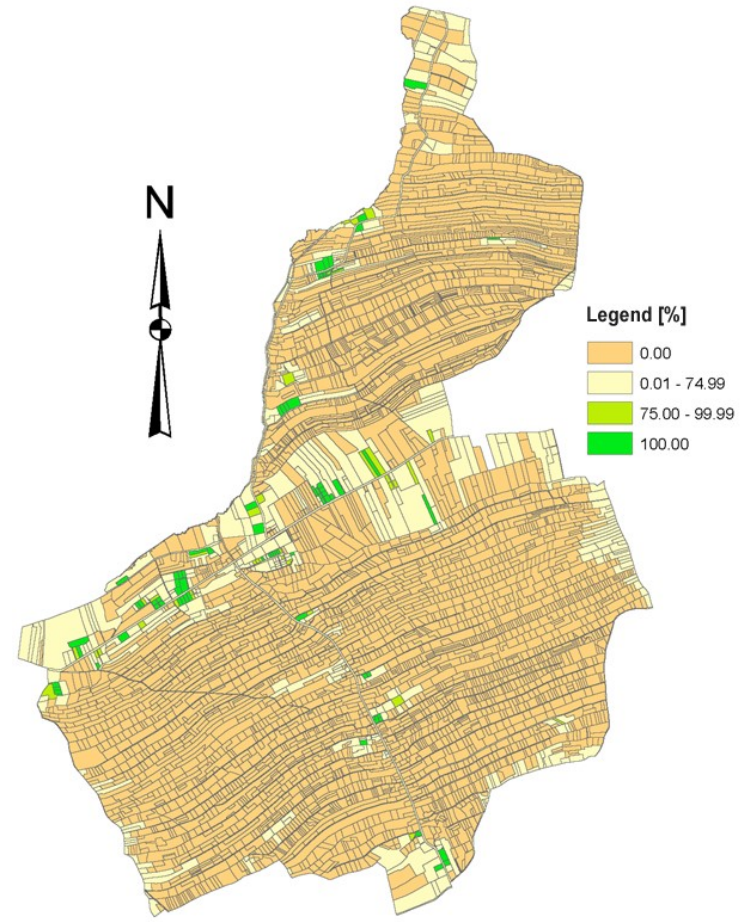

Fig. 11. The legal boundary of the registry parcels on the example of the Nieczajna precinct, source: [7].

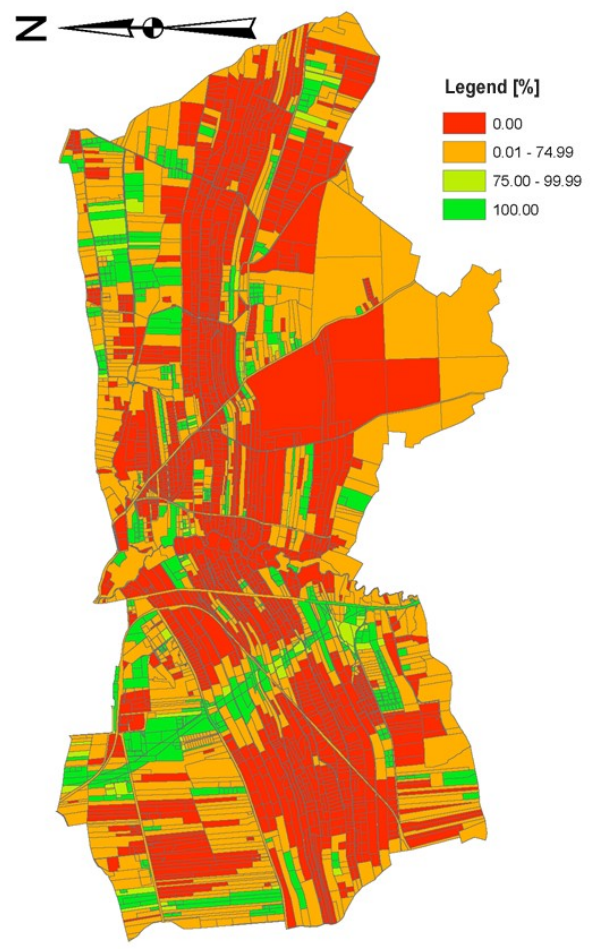

Fig. 12. Analysis of parcel plots with regard to the error of the average location of the border point with respect to the geodetic control network of the 1st class on the example of the Bagienica precinct, source: own study.
In order to illustrate the situation regarding the quality of cadastral data in the city and commune of Dąbrowa Tarnowska, a ranking list has been prepared on the basis of the above-mentioned surveys, due to the quality of the data held.

For this purpose, the percentage share of plots fulfilling the given criterion is compared to the total number of registered plots within. Selected criteria are in sequence: no discrepancies between the graphic part and the descriptive part in the number of parcels, no differences in area between the graphic and descriptive part, surface area specified up to 0.0001 ha, disclosed in the land and mortgage register (in the existing and electronic form), displayed in the PESEL or REGON attribute database, displayed in the owner's address database in the case of individuals or registered office with regard to institutions, each border point is legally valid and the position error of each border point is in the range 0.00 to $0.30 \mathrm{~m}$.

The list presented below shows the state of cadastral data only in relation to the studied area (2 registry units). In comparison with the city and commune of Dąbrowa Tarnowska, the best quality of cadastral data is provided by the following divisions: Dąbrowa, Ruda and Bagienica.

Table 1. Calculation of the cadastral data quality factor (source: own study).

\begin{tabular}{|c|c|c|c|c|c|c|c|c|c|c|c|}
\hline \multirow{4}{*}{$\begin{array}{l}\text { Place in } \\
\text { the } \\
\text { ranking }\end{array}$} & \multirow{4}{*}{ Precinct } & \multicolumn{8}{|c|}{ evaluation criterion number: } & \multirow{4}{*}{ SUM } & \multirow{4}{*}{$\mathbf{w}_{\mathrm{k}}$} \\
\hline & & 1 & 2 & 3 & 4 & 5 & 6 & 7 & 8 & & \\
\hline & & \multicolumn{8}{|c|}{ weight of the criterion: } & & \\
\hline & & 1.0 & 2.0 & 1.0 & 2.0 & 1.0 & 1.0 & 2.0 & 3.0 & & \\
\hline 1 & Dąbrowa & 100.0 & 25.8 & 100.0 & 84.8 & 83.7 & 95.5 & 27.7 & 26.1 & 734.1 & 100.0 \\
\hline 2 & Ruda & 100.0 & 30.6 & 100,0 & 86.6 & 83.7 & 92.1 & 22.9 & 23.0 & 725.0 & 97.0 \\
\hline 3 & Bagienica & 100.0 & 21.1 & 100.0 & 79.5 & 74.6 & 90.6 & 16.9 & 18.7 & 656.3 & 74.8 \\
\hline 4 & Morzychna & 100.0 & 21.8 & 30.3 & 77.1 & 52.5 & 97.2 & 21.8 & 23.1 & 590.7 & 53.5 \\
\hline 5 & Gruszow Mały & 99.1 & 17.0 & 29.8 & 82.2 & 73.4 & 93.4 & 11.2 & 16.9 & 567.2 & 45.9 \\
\hline 6 & Laskówka Choraska & 99.9 & 7.3 & 13.1 & 69.9 & 84.7 & 98.4 & 11.6 & 12.0 & 509.7 & 27.2 \\
\hline 7 & Żelazówka & 100.0 & 6.7 & 11.5 & 70.4 & 86.0 & 98.7 & 9.5 & 9.4 & 497.6 & 23.3 \\
\hline 8 & Gruszów Wielki & 100.0 & 6.5 & 13.6 & 72.7 & 79.2 & 97.6 & 7.1 & 7.4 & 485.2 & 19.3 \\
\hline 9 & Lipiny & 100.0 & 3.4 & 12.9 & 73.6 & 81.6 & 95.0 & 7.3 & 7.2 & 479.7 & 17.5 \\
\hline 10 & Smęgorzów & 99.9 & 3.7 & 6.2 & 77.5 & 79.1 & 94.8 & 4.3 & 5.6 & 467.8 & 13.6 \\
\hline 11 & Sutków & 100.0 & 4.8 & 11.3 & 64.7 & 80.3 & 97.2 & 7.7 & 7.8 & 466.6 & 13.2 \\
\hline 12 & Szarwark & 100.0 & 2.5 & 4.0 & 76.7 & 82.1 & 94.7 & 2.6 & 2.9 & 453.1 & 8.9 \\
\hline 13 & Brnik & 100.0 & 4.2 & 7.9 & 66.0 & 75.4 & 96.8 & 6.4 & 6.1 & 451.6 & 8.4 \\
\hline 14 & Nieczajna & 99.8 & 2.2 & 3.5 & 74.6 & 59.9 & 98.6 & 2.0 & 2.1 & 425.7 & 0.0 \\
\hline & MAX & 100.0 & 30.6 & 100.0 & 86.6 & 86.0 & 98.7 & 27.7 & 26.1 & 734.1 & 100.0 \\
\hline & MIN & 99.1 & 2.2 & 3.5 & 64.7 & 52.5 & 90.6 & 2.0 & 2.1 & 425.7 & 0.0 \\
\hline & AVERAGE & 99.9 & 11.3 & 31.7 & 75.5 & 76.9 & 95.8 & 11.4 & 12.0 & 536.5 & 35.9 \\
\hline
\end{tabular}

Taking into account the carried out research, it has been established that all areas have smaller or larger gaps in the cadastral database. Therefore, the task of the presented classification is to help in defining the schedule of modernization of land and building registry. First of all the attention should be paid to the rural areas, i.e. Nieczajna, Brnik, Szarwark, Sutków, Smęgorzów and Lipiny.

Taking into account that the precincts could have obtained a total of 1300 points, they are summarized in Table 2 of the scope with reference to the reference condition. This list clearly indicates that the data in the analysed area are not complete and accurate.

\footnotetext{
* Corresponding author: jaroslaw.taszakowski@urk.edu.pl
} 


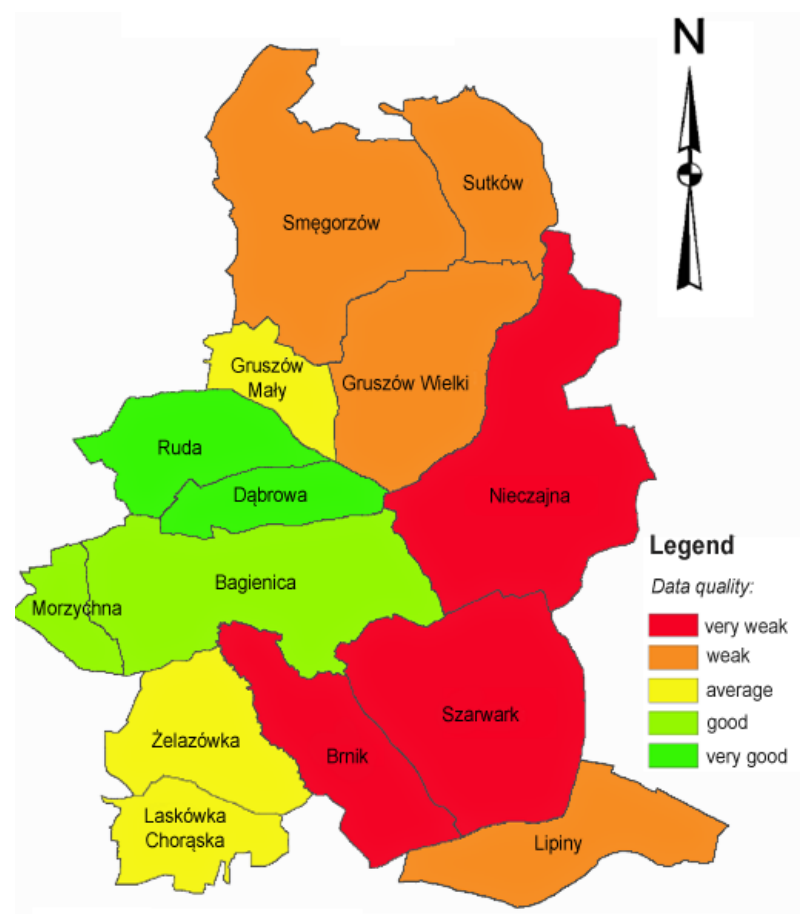

Fig. 13. The quality of cadastral data in relation to the city and commune of Dąbrowa Tarnowska, source: own study.

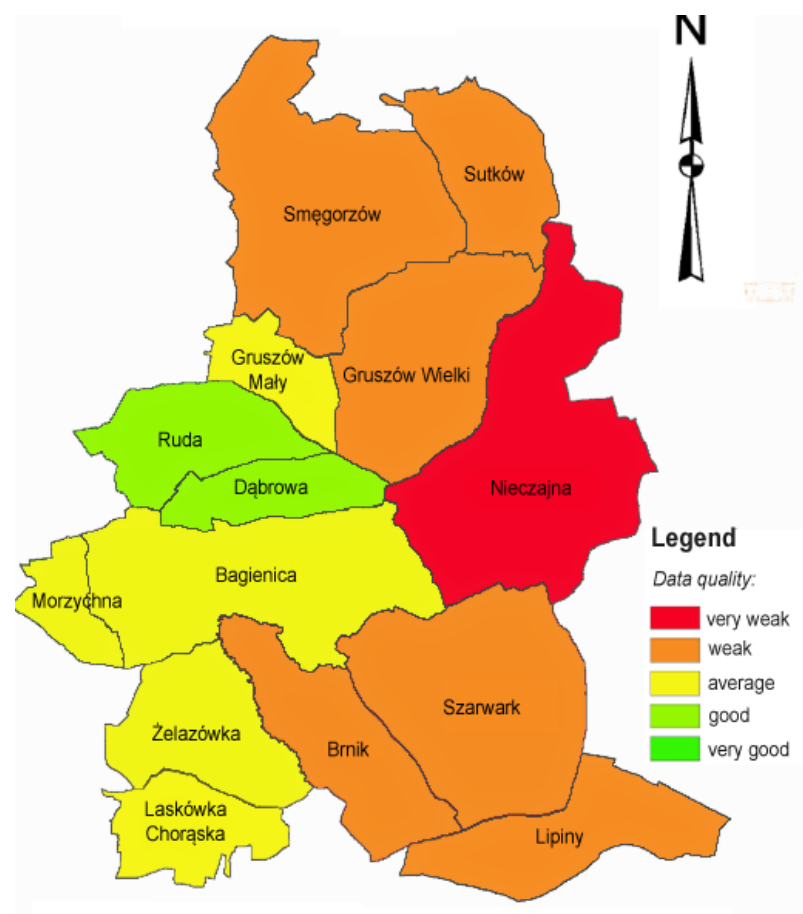

Fig. 14. The quality of cadastral data in relation to the master status. source: own study
Table 2. Quality factor of cadastral data with reference to the master status (source: own study).

\begin{tabular}{|c|c|c|c|c|c|c|c|c|c|c|c|}
\hline \multirow{4}{*}{$\begin{array}{l}\text { Place in } \\
\text { the } \\
\text { ranking }\end{array}$} & \multirow{4}{*}{ Precinct } & \multicolumn{8}{|c|}{ evaluation criterion numer: } & \multirow{4}{*}{ SUM } & \multirow{4}{*}{$\mathbf{W}_{1 \%}$} \\
\hline & & 1 & 2 & 3 & 4 & 5 & 6 & 7 & 8 & & \\
\hline & & \multicolumn{8}{|c|}{ weight of the criterion: } & & \\
\hline & & 1.0 & 2.0 & 1.0 & 2.0 & 1.0 & 1.0 & 2.0 & 3.0 & & \\
\hline 1 & Dąbrowa & 100.0 & 25.8 & 100.0 & 84.8 & 83.7 & 95.5 & 27.7 & 26.1 & 734.1 & $56 \%$ \\
\hline 2 & Ruda & 100.0 & 30.6 & 100.0 & 86.6 & 83.7 & 92.1 & 22.9 & 23.0 & 725.0 & $56 \%$ \\
\hline 3 & Bagienica & 100.0 & 21.1 & 100.0 & 79.5 & 74.6 & 90.6 & 16.9 & 18.7 & 656.3 & $50 \%$ \\
\hline 4 & Morzychna & 100.0 & 21.8 & 30.3 & 77.1 & 52.5 & 97.2 & 21.8 & 23.1 & 590.7 & $45 \%$ \\
\hline 5 & Gruszów Mały & 99.1 & 17.0 & 29.8 & 82.2 & 73.4 & 93.4 & 11.2 & 16.9 & 567.2 & $44 \%$ \\
\hline 6 & $\begin{array}{l}\text { Laskówka } \\
\text { Choraska }\end{array}$ & 99.9 & 7.3 & 13.1 & 69.9 & 84.7 & 98.4 & 11.6 & 12.0 & 509.7 & $39 \%$ \\
\hline 7 & Żelazówka & 100.0 & 6.7 & 11.5 & 70.4 & 86.0 & 98.7 & 9.5 & 9.4 & 497.6 & $38 \%$ \\
\hline 8 & Gruszów Wielki & 100.0 & 6.5 & 13.6 & 72.7 & 79.2 & 97.6 & 7.1 & 7.4 & 485.2 & $37 \%$ \\
\hline 9 & Lipiny & 100.0 & 3.4 & 12.9 & 73.6 & 81.6 & 95.0 & 7.3 & 7.2 & 479.7 & $37 \%$ \\
\hline 10 & Smęgorzów & 99.9 & 3.7 & 6.2 & 77.5 & 79.1 & 94.8 & 4.3 & 5.6 & 467.8 & $36 \%$ \\
\hline 11 & Sutków & 100.0 & 4.8 & 11.3 & 64.7 & 80.3 & 97.2 & 7.7 & 7.8 & 466.6 & $36 \%$ \\
\hline 12 & Szarwark & 100.0 & 2.5 & 4.0 & 76.7 & 82.1 & 94.7 & 2.6 & 2.9 & 453.1 & $35 \%$ \\
\hline 13 & Brnik & 100.0 & 4.2 & 7.9 & 66.0 & 75.4 & 96.8 & 6.4 & 6.1 & 451.6 & $35 \%$ \\
\hline 14 & Nieczajna & 99.8 & 2.2 & 3.5 & 74.6 & 59.9 & 98.6 & 2.0 & 2.1 & 425.7 & $33 \%$ \\
\hline & MAX & 100.0 & 30.6 & 100.0 & 86.6 & 86.0 & 98.7 & 27.7 & 26.1 & 734.1 & $56 \%$ \\
\hline & MIN & 99.1 & 2.2 & 3.5 & 64.7 & 52.5 & 90.6 & 2.0 & 2.1 & 425.7 & $33 \%$ \\
\hline & VERAGE & 99.9 & 11.3 & 31.7 & 75.5 & 76.9 & 95.8 & 11.4 & 12.0 & 536.5 & $41 \%$ \\
\hline
\end{tabular}

\section{Summary}

On the basis of the conducted research, it can be concluded that the cadastral database in the area of the city and commune of Dąbrowa Tarnowska is not coherent at the moment. Data from the graphic part do not coincide at $100 \%$ with the data of the descriptive part. There are a lot of differences that have enormous significance in civil law proceedings. The register under investigation is also not a complete or accurate database, in many cases, the information was insufficient (for example, for addresses), instead of reliable information, also the message "no data in swde" appeared. Cadastral data in the Dąbrowa centre should be considered as upto-date. Data modifications are quite frequent and mainly concern the last three years.

At present, basing on the research and analysis carried out, it should be stated that the city and commune of Dąbrowa Tarnowska are not ready for the implementation of the Integrated Cadastre System. The collected cadastral data constitute a huge amount of information, but do not meet the necessary requirements for the correct operation of IPIS.

\section{References}

1. O. Demir, and Y.E Çoruhlu, Determining the property ownership on cadastral works in Turkey. Land Use Policy, 26, pp. 112-120 (2009)

2. M. Siejka, M. Ślusarski, and M. Zygmunt, 3D+time Cadastre, possibility of implementation in Poland. Survey Review, 46(335), pp. 79-89 (2014)

3. A.C. Aydinoglu, R. Bovkir, Generic land registry and cadastre data model supporting interoperability based on international standards for Turkey. Land Use Policy, 68, 59-71 (2017)

4. D.Steudler, A.Rajabifard, I.P.Williamson, Evaluation of Land administration systems. Land Use Policy 21(4), 371-380, (2004)

5. M. Mika, An Analysis of Possibilities for the Establishment of a Multipurpose and Multidimensional Cadastre in Poland. Land Use Policy, 77: 446-53 (2018)

6. K. Kocur-Bera. Data compatibility between the Land and Building Cadaster ( $L B C$ ) and the Land Parcel Identification System (LPIS) in the context of area-based payments: A case

\footnotetext{
* Corresponding author: jaroslaw.taszakowski@urk.edu.pl
} 
study in the Polish Region of Warmia and Mazury. Land Use Policy, 65, 143-53 (2018)

7. Coucil of Ministers' decree of January 17, 2013 on the integrated property information system (Journal of Laws 2013 item 249)

8. M. Benhamu, Y Doytsher, Toward a spatial $3 D$ cadastre in Israel, Computers, Environment and Urban Systems, 27, 4, 359374 (2003)

9. K.L. Kim, S.W. Hwang Bo, G.H. Lim, and S.J. Park, A Study on the Development Cadastral Model for $3 D$ Cadastre Registration, Journal of Korea Society of Surveying, Geodesy, Photogrammetry, and Cartography, 23, 2, 129-136 (2005)

10. P. Molen, Institutional aspects of $3 D$ cadastres, Computers, Environment and Urban Systems, 27, 4, 383 -394 (2003)

11. J. Stotoer, P. Oosterom, $3 D$ Cadastre in an International Context: Legal, Organizational, and Technological Aspects, Taylor \& Francis, New York (2006)

12. E. Gołąbeska, The Integrated Cadastral System as a factor of real estate market development. Real estate world 2 (76) (2011) (in Polish)

13. http://www.gugik.gov.pl/geodezja-i-kartografia

14. P. Pochwatka, T. Teterycz, U. Litwin, and A. Bitner, Cartographic Visualization in The Real Estate Market Investigation with the Use of GIS Tools, 2017 Baltic Geodetic Congress (Geomatics) pp. 105-109 (2017)

\footnotetext{
* Corresponding author: jaroslaw.taszakowski@urk.edu.pl
} 